\title{
Field Work Practice in Correctional Setting: Indian Social Work Perspectivec
}

\author{
Sanjoy Roy* \\ Department of Social Work, University of Delhi, India
}

Submission: September 19, 2017; Published: October 16, 2017

*Corresponding author: Sanjoy Roy, Department of Social Work, University of Delhi, India, Email: sanjoyroy30@gmail.com

\begin{abstract}
Field work programme provides opportunities to the social work students/learners to apply his/her theoretical knowledge skilled in the classroom appropriately in different practical situations whether it is in the community or social welfare or correctional agencies/settings. It could serve a kind of social laboratory where the students are taught to test their theoretical knowledge and skills against practical situations of social living.
\end{abstract}

Practically in India, the Correctional setting works under a combination of four major sub-systems i.e. police, prosecution, judiciary and the correctional services. Each sub-system is expected not only to play its own statutory role to contribute towards the achievement of the main objectives of the Criminal Justice system as a whole but also to strengthen each other's role in a strenuous manner. But the ground reality shows that each of these sub-systems usually tend to function as a system of its own and, many a time, works at cross purposes with the other segments of the Criminal Justice System. India's criminal justice system has not been able to deliver on what is anticipated of it and is, in fact, under mammoth sprain because of the problems in all the components law enforcement, adjudication and correction and, therefore, the need for reforms is the question of the hour.

Therefore, social worker play prominent roles in administrative and practice positions in correctional setting with all the law enforcing agencies to prevent this kind of social problem in the society and also to work on rehabilitation and to provide and secure social justice.

Keywords: Correctional setting; Social work; Criminal justice system; Roles of social workers; Social worker's intervention cycle

\section{Introduction}

Field work programme provides opportunities to the social work students/learners to apply his/her theoretical knowledge skilled in the classroom appropriately in different practical situations whether it is in the community or social welfare or correctional agencies/settings [1-7]. It could serve a kind of social laboratory where the students are taught to test their theoretical knowledge and skills against practical situations of social living. Now field work is recognized as a major and fundamental component in professional social work education because of its implications for professional practice [8-15].

Social-work services have been offered in prisons/ correctional setting for nearly a century in USA and were advanced by the advocacy efforts of Kenneth Pray, the former dean of the University Of Pennsylvania School of Social Work (now the School of Social Policy and Practice). Pray's impassioned pleas for social-work involvement with prisoners is a must read for every social worker who wonders why our involvement is necessary and what we would do while there Pray [16]; Pray \& Towle [17]. Unfortunately, despite Pray's efforts, social work has assumed an ambivalent stance toward its work in prisons, perhaps because of the conflicting values of the profession and the institution. However, the explosion in the prison population experienced since the 1980s, along with the federal court actions described above, has created an ever-expanding need for the unique set of professional skills that social workers bring to correctional institutions.

The NASW's [18] recognizes the importance of providing quality services to the incarcerated population in its policy statement related to social work in the criminal justice system. Social Work Speaks is a comprehensive collection of policies adopted and revised by the NASW's key policymaking body, the Delegate Assembly, and, in relevant part, the policy recommendations vis-à-vis the incarcerated population challenge social workers to do the following:

a. Provide ongoing advocacy to address the disproportionate rate of incarceration of racial or ethnic minorities, juveniles, women, and undocumented individuals.

b. Provide culturally competent treatment to and intervention for the growing populations of inmates with mental illness, substance issues, or co-occurring disorders. 
c. Seek access to quality health care, medications, nutrition, treatment, and rehabilitation programs for inmates.

d. Identify appropriate educational and vocational opportunities to assist incarcerated individuals with transitioning back into their communities; and

e. Provide advocacy and social-work leadership to establish national policy on criminal justice issues.

According to the American Heritage Dictionary, the criminal justice system is defined as "the system of law enforcement, the bar, the judiciary, corrections, and probation that is directly involved in the apprehension, prosecution, defense, sentencing, incarceration, and supervision of those suspected of or charged with criminal offenses. The principal objective of a criminal justice system is to impart a sense of security to the people".

Social work, being goal-oriented and intervention-oriented professional education, aims at helping social work trainees to acquire and internalize deep knowledge of the theory and the techniques for achieving social work objectives. The social work trainee has to learn every practical aspect within his/her two years of postgraduate training programme. Further, they have to acquire an understanding of the principles, concepts, policies and processes which constitute the profession of social work. Through the field work programme social work trainee is prepared to be a competent professional social worker. The main objective of field work in social work education is to provide the opportunities to the students to learn and practice the professional skills in the field that are taught in the class. A trainee social worker while in the field tries to interpret and diagnose the situation in the background of the knowledge and understanding and thus helps adjustment to the situations. Thus field work aims at the development of the students' capacities and capabilities as a realistic worker. Direct contract and touch with the people helps students grow in knowledge about people and their problems providing them with emotional maturity, power of judgment and stability in action.

The Second Review Committee on Social Work Education (1980) has mentioned the following objectives of field work:

a. Development of professional skills through learning to use knowledge for the study and analysis of problems and selection of appropriate means to solve them.

b. Development of skills in problem solving at the macro and micro levels.

c. Integration of classroom learning with field practice.

d. Development of skills required for professional practice at the particular level of training.

e. Development of professional attitude, values, and commitment and

f. Development of self-awareness and professional ideal.
The main objectives of field work as follows:

i. Develop professional skills through learning how to utilize the knowledge for the study of the relevant fact, the analysis of problem and selection of the appropriate means of problem solving.

ii. The development of skills for problem solving in work at the micro level (individual, family, small group, community etc.) and change at the macro level in social institutions and process.

iii. Provide concurrent opportunity for the integration of class room learning in the field practice and vice versa.

iv. Develop skills require for professional practice at the particular level of training.

v. Develop professional attitude involving impartiality, non judgmental attitudes, objectively.

vi. Develop professional values and commitments such as respect for human dignity and worth and the right to participation and self determination compatible with the good of society.

vii. Develop awareness of self and the ways in which psychological and cultural factors affects the perceptions and responses to others and

viii. Develop the professional ideal.

In correctional setting, social workers may work in jails, prisons, community-based organizations and primary health care agencies that serve ex-offenders, and in the courts. Social workers are committed to social justice on both the micro, or individual, and macro, or large-scale, levels. Practitioners on the macro level usually focus on helping groups, communities and society as a whole. This is why promoting social justice is often linked with macro practice. Macro-level social workers try to promote equality among all people regardless of gender, race, religious beliefs or economic background.

\section{Correctional institutions}

Correctional institution is nothing but the penal of institution maintained by the government.

Types of correctional institutions for institutional treatment:

a. Prisons

b. Observation homes

c. Special homes

d. Children homes

e. After-care organization

f. Protective home for women

g. Short stay home 
h. Beggars home.

a. Prisons: Prisons are the place in which criminals could be securely confined and this containment function had continued to predominate in spite of the gradual emergence of other alms for imprisonment, such as deterrence or rehabilitation.

b. Observation homes: Observation homes established for the temporary of any juvenile in conflict with law during the pendency of a case before the juvenile justice board. Every juvenile who is not placed under the change of parent or guardian is sent to an observation home. He/she initially kept in a reception unit of the observation home for preliminary enquiries. Care and classification of the juveniles is done according to his/her age group, such as 7-12 years, 12-16 years and 16-18 years, giving due to consideration to physical and mental status and degree offence committed.

c. Special homes: Under juvenile justice (care and protection) Act, 2000 state government is empowered for establishing and maintaining special homes for reformation and rehabilitation of juveniles in conflict with law. Such homes are maintained by the government or by certified voluntary organization. In these homes, various types of services are provided which necessary for the re-socialize of a juvenile.

d. Children homes: Children homes are contemplated for the reception of children in need of care and protection during the pendency of enquiry even for their stay as case may be. Every child's home is provided with facilities of accommodation, maintenance, education, vocational training, rehabilitation and development character and abilities.

e. After-care organizations: These organizations are meant for the juveniles discharge from the children's homes and special homes. The purpose of the aftercare organization is help in the rehabilitation and resettlement of children through extended educational and vocational training facilities including job placement. The stay in aftercare organization is restricted to a maximum of three years over seventeen years age till s (he) attains the age of till s (he) attains the age of 20 years on the basis of a discharge report prepared by competent.

f. Protective home for women: The protective home and corrective institutions are established Under the Immoral Traffic (prevention) Act by Directorate of Social Welfare. It admits girls and women, who are rescued from brothels, are abducted and kidnapped (section 366 IPC), raped (section 376 IPC) and are in moral danger. The girl and women can get admission only through the orders of the court and will continue to stay till the Court gives the order for her restoration or rehabilitation. g. Short stay homes: It is institution established under the Immoral Traffic (prevention) Act (ITPA) by Government/ Union Territory Administration. The purpose is to provide ort temporary shelter to the needy women/girls in distress, pending their restoration or readjustment in their families or admission in suitable institutes. The short stay home provides admission to girls and women in the age group of 18 to 45years. Who are destitute distress deserted or are in moral danger. The duration of stay in short stay home is districted to 6 months. The home provides safe custody, boarding, lodging, food, clothing medical care and vocational training like tailoring and knitting. Pt provides specialties like food, shelter, accommodation, medical care non formal education and vocational training. The superintendent of short stay home makes all efforts to restore or, reintegrate the women/girl in her family or through marriage.

h. Beggars home: These homes are established under the Anti-Beggary laws of the state government. Unfortunately, there is no Anti-Beggary Act formulated at the national level. These Acts are formulated by the state at their own initiatives. Reception centers and Bagger Homes are established under the Act. The Beggar's home provides specialties like food, shelter, accommodation, medical care, non-formal education and vocational training to beggars so they are economically rehabilitated into society.

Types of correctional institutions for Non-institutional treatment
a. Probation
b. Parole
c. Hybrid treatment
d. Community service
e. Work release

Non-institutional treatments are community-based correctional programmes that help in the reintegration of offenders. Community-based correction is an effective method of accomplishing the changes in the behavior of the offender by helping him to become a law-abiding citizen.

a. Probation: The term probation is used denote the status of a person placed on probation, to refer to the subsystem of the criminal justice system. Probation is an alternative to the prison/ special home. It is a sentence that does not involve confinement but may involve conditions imposed by the Court Juvenile Justice Board, usually under the supervision of a probation officer.

b. Parole: Parole is a treatment programme in which the offender, after serving part of a term in correctional institution, is conditionally released under the supervision and treatment of a Parole Officer. Parole is not of every individual in prison. It is viewed as a privilege granted to a prisoner for good behavior and 
process while in prison and is considered useful in rehabilitation outside.

c. Hybrid Treatment: This is a kind of correctional treatment in a collaborative enterprise between corrections and treatment professionals.

d. Community service: Community service, the offenders must give personal time to perform takes that are valued in the community. This programme is especially meant for juvenile and adolescents who are placed in community service organization.

e. Work release: In work release programme. The inmates are released from incarceration to work. They enable the offenders to engage in positive contacts with the community, assuming of course, that work placement is satisfactory. They permit offenders to provide some support for themselves and their families. This can eliminates the self- concept of failure that may be the result of loss the supportive role.

\section{Correctional social workers/prison social workers in usa}

Social workers in criminal justice settings often assess new arrivals to the prison, develop treatment and support plans for inmates, provide individual therapy and psychosocial educational support groups, provide referrals to medical or mental-health services, and monitor the progress and compliance of inmates in treatment. As in most settings, social workers in criminal justice facilities document inmates' progress in their health records, write progress reports, and, in some institutions, present their cases at "grand rounds" or in other institutional forums.

In many prison systems, the initial assessment of the inmate involves a battery of psychological tests and interviews with social workers and other treatment professionals to determine the presence of acute (psychosis, anxiety, depression, suicide ideation) and chronic conditions (severe and persistent mental illness, history and current manifestations of trauma and substance abuse). During the assessment phase the social worker determines the inmate's eligibility for services and treatment and, in theory if not in reality, begins to plan for the inmate's discharge. The latter is no small task: in the United States the vast majority of prisoners return to the community; about 1,600 prisoners a day are released from state and federal prisons Travis [19].

Based on the assessment data, intervention and treatment plans are developed, taking into consideration the unique needs of the inmate; these may include a combination of individual counselling, involvement in a specialized treatment group, and case management services. A growing body of research indicates that strengths-based case management is an effective response to inmates in need of skills in daily living or those who struggle with alcohol and drug addiction or with serious physical or mental-health issues Bauserman [2]. Hess, Vanderplasschen,
Rapp, Broekaert, and Fridell (2007) looked at the relevant body of research from 15 randomized studies of case management for persons with substance-abuse disorders and found a moderate effect size in the effectiveness of case management in linking clients with treatment and other services. Although a smaller effect was detected, Hess and colleagues also found that case management services had a positive impact on long-term drug use and may have contributed to a reduction in criminal behavior [20-25].

\section{Compassion vs. public safety}

Social workers must have compassion and empathy for the people they work with, according to the U.S. Bureau of Labor Statistics [26-30]. These professional expectations can be in conflict, however, with society's needs for public safety, according to "Criminal Justice Social Work in the United States-Adapting to New Challenges." A person who commits a crime because of mental health issues may need to be treated differently than an offender who committed the crime in full awareness that what he did was wrong. The social worker can help other members of the legal system, such as lawyers and judges, as well as juries understand the difference between the two offenders.

\section{Family issues}

Some social workers may work with children and families who have entered the criminal justice system. The social worker might help a woman who was a victim of domestic violence to find a safe place for herself and her children, or apply for benefits such as food stamps [31-35]. On the other hand, social workers help children in the foster care system. They may handle adoptions or locate and work with foster families when children have been removed from the home by the court because of neglect or abuse.

\section{Working with minors}

Juveniles who are in the system because they have committed or been the victim of crimes may need the assistance of a social worker for issues such as a minor's ability to testify. Other issues relevant to minors include their ability to make medical decisions, child custody issues or the necessity to appoint a guardian if a parent dies or becomes incapacitated. Social workers in the criminal justice system who work with children often become advocates for different legal standards for children as compared to adults, according to the National Association of Social Workers.

\section{Other Roles}

Although any social worker might be required to provide courtroom testimony, social workers in the criminal justice system have many roles. Some work as researchers to obtain relevant information about a particular case. Others serve as probation officers or case managers. A social worker in a jail or prison might function as a therapist for prisoners. Forensic social workers could draft reports about defendants that include 
information about the defendant's decision-making capabilities, medical and mental health, education or test results, according to a November 2012 article in "NASW News" [18]. Other social workers provide therapy to sex offenders, perform conflict mediation or act as victim advocates. Social workers help crime victims manoeuvre through complex legal processes and offer a helping hand on the road to recovery. On the other side of the scale, social workers in public defenders' offices ensure defendants have a right to explain their story, and they promote the benefits of rehabilitation.

\section{Skills you required to intervene}

Social work positions within corrections encompass a wide range of skills and specialized services, including:
i. Discharge planning
ii. Case management
iii. Comprehensive need assessment of the offenders

\author{
iv. Program delivery \\ v. Individual/family/group counseling/group therapy \\ vi. Crisis intervention \\ vii. Negotiation and mediation \\ viii. Teaching \\ ix. Community capacity building and \\ x. Advocacy (individual and systemic).
}

Social workers can play their interventional role through law enforcement agencies time to time in different areas mentioned in the above. Here social worker also plays their roles as mediator, catalyst, therapist, teacher, researcher, guide, communicator, liazoning, care giver etc. depending on the veracity of the crimes/issues. Social worker can also be placed in the following areas of intervention where they also would have some roles to play Figure 1.

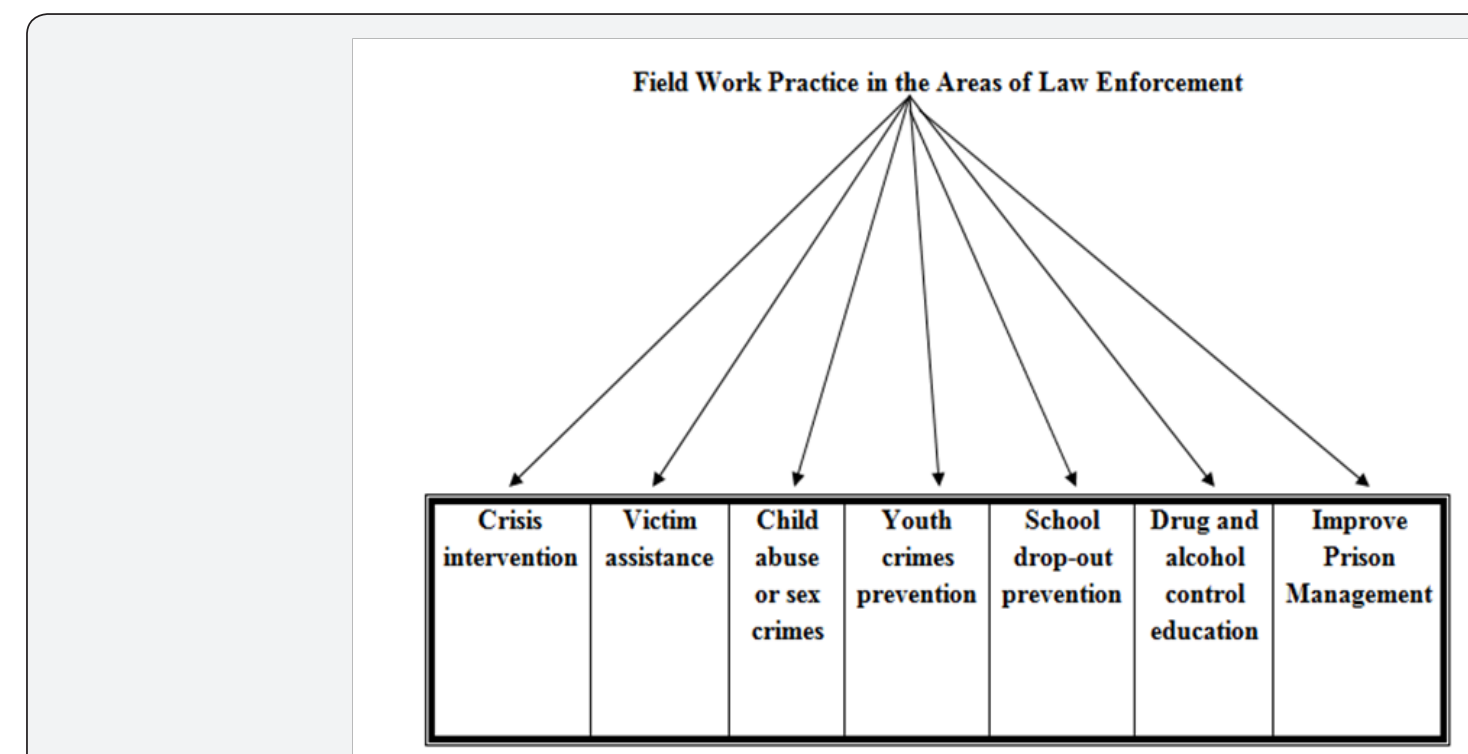

Figure 1: Field Work Practice in the Areas of Law Enforcement.

Social workers act independently. They make decisions based on their experience, judgment, and clinical assessment skills. At the same time, they need to work well in a team setting to provide effective interventions and treatments that contribute to an offender's rehabilitation and safe return to the community.

Use of Social Work Methods in Correctional Setting: The student social worker can use all the social work methods during their field work placement in the correctional setting.

Social Casework in correctional settings: Social case work involves a secure face to face relationship essentially basis in working with individuals and their problem. The practice of the case work is being governed by five key basic assumptions that are helpful in serving the offender which are as follows:

a. Every individual must be seen as a person of worth and dignity. b. Behavior, whether acceptable unacceptable to the community, express a need of the individual.

c. An individual can and will change her/his behavior if the right time and in the right amount.

d. If the offer of help is given before the problem become serious aggravated, the repose is likely to be better; and

e. The family is the most influence force in the development of personality in the crucial early years.

f. Social Group work in correctional settings.

Group work with delinquents and adult offenders is usually considered as a powerful method for modifying behavior and attitude. The purpose of group work in correctional settings is:

a. To strengthen the emotional security of the offender within the framework of the group so that he does not feel 
alone and helpless but also moves towards not being wholly dependent on it.

b. To strengthen the offender's independence by helping him to actually participate in the group discussion, and not to submit to a gang leader or a powerful sub-group.

c. The introduction of an adult (group worker) who represent the values of a society offenders often reject, but who, because of his accepting attitude represent adult security and love.

d. To provide an opportunity to gain inner resilience and status with the group through accomplishment in activities by society.

Community organization in correctional setting: Community organization has an important role in rehabilitation and reintegration of released offenders into mainstream of the society. At the same time community organization is used widely for the prevention of crime and delinquency. The convicts after completing the sentence usually face problems in the adjustment with family, relatives, peer group, neighborhood and even for acquiring employment. Social workers consider family to be an important unit that can provide support released offenders to take care of his various needs and aspirations. For these social worker has to mobilize the resources for meeting the needs of individuals and establishing support groups on whom one can rely upon, as and when necessary.

Social action in correctional setting: Social action has too imperative role to play in the field of corrections. Among others, the process of Public Interest Litigation (PIL) could be one of the main issues. The under-trials are kept in the jail for years without their cases even being processed, let alone decided. In such cases social workers have approached the court to get justice for such under trails that have spent years in judicial custody then required in the jails just waiting for their trails to begin. Therefore lobbying also work as an important technique here.

Social work research and social welfare in correctional settings: There is need to evaluate the current programmes and services in the field of corrections to bring about certain development in this setting. Extensive research studies are required 'in order to select alternative to the institutional care. At the same time, it is desirable to measure the relative efficacy of institutional and non-institutional services in the field of corrections.

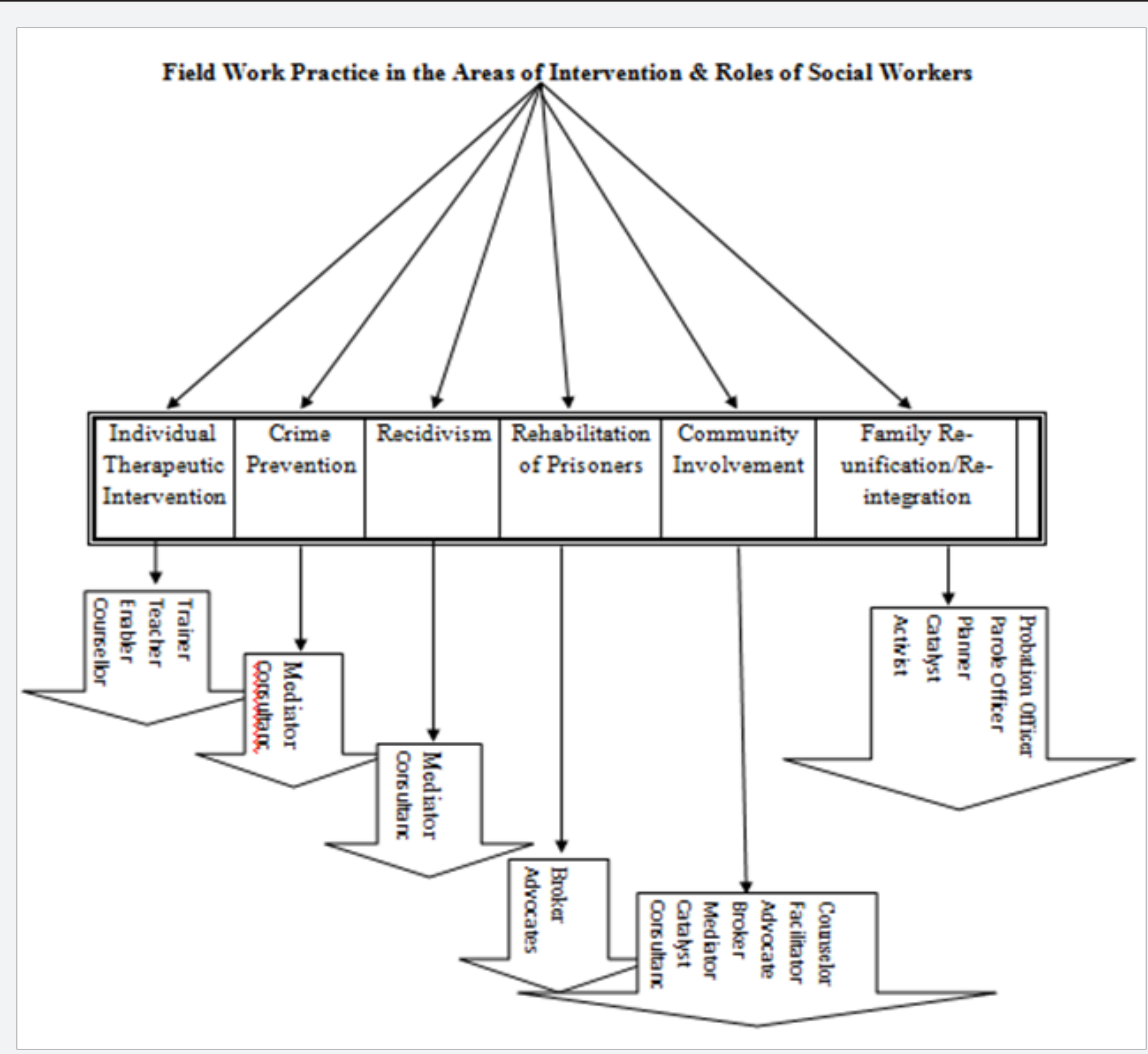

Figure 2: Field Work Practice in the Areas of Intervention \& Roles of Social Workers

The social work professional could do some work with other personnel in the correctional setting. Custodial staff is generally overburdened with the security duties Figure 2. One after comes cross the question whether custodial staff such as warder, head warder, assistant jailor, deputy jailors, jailors, etc., are meant only for custody and not for correctional treatment [36-38]. 

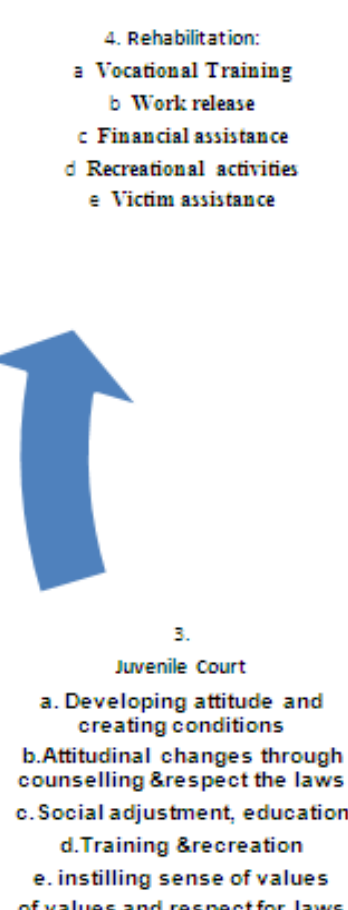

of values and respect for laws

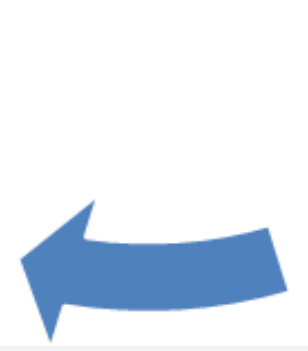

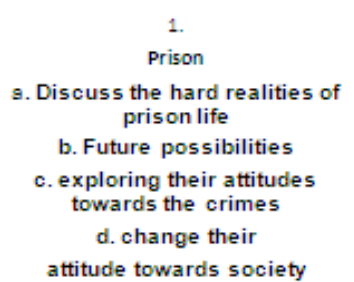

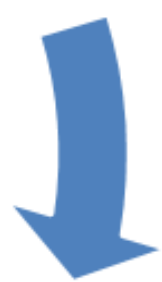

2

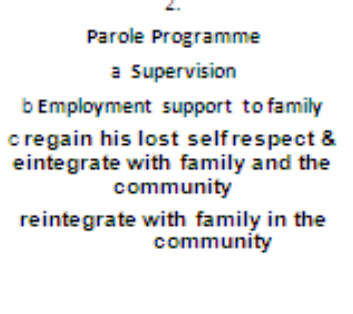

Figure 3: Social Worker's Intervention Cycle during Field Work.

Is correctional treatment the responsibility of welfare officer, doctor or psychiatrist only..? It seems to be a misleading dichotomy Figure 3. Social worker should conduct some training and some activities for attitudinal and behavioral change of offenders so that they can adjust with the society.

\section{Conclusion}

Social work has a momentous role to play in correctional setting. With its goal of restoring and enhancing the social functioning, social work professionals/students through different designation as caseworker, welfare officer, social worker, probation officer or prison officer help the offenders in correcting and modifying their personality, attitude and to reintegrate them back into the society.

\section{References}

1. American Heritage Dictionary of the English Language, Fourth Edition.

2. Bauserman R, Richardson D, Ward M, Shea M, Bowlin C, et al. (2003) HIV prevention with jail and prison inmates: Maryland's prevention case management program. AIDS Educ Prev 15(5): 465-480.

3. Bureau of Police Research \& Development (2012) Indian Police: An Introduction \& statistical overview, p. 2.

4. Castro A (2013) Inside California Department of Corrections and Rehabilitation News.

5. Covington SS, Bloom BE (2006) Gender-responsive treatment and services in correctional settings. Women \& Therapy, 29(3/4): 9-33.

6. DuBois B, Miley KK (1999) $3^{\text {rd }}$ Edition Social Work an Empowering Profession.
7. Epperson MW, Roberts LE, Ivanoff A, Tripodi SJ, Gilmer CN (2013) To what extent is criminal justice content specifically addressed in MSW programs? Journal of Social Work Education 49(1): 96-107.

8. Ganesh Indira M (2007) Next Steps: Taking the Special Cell Process A head. Tata Institute of Social Sciences, Mumbai, India.

9. Gibelman M (1995) What social workers do. NASW Press, Washington, DC, USA, pp. 397.

10. Glaze L, Maruschak L (2010) Parents in prison and their minor children (Bureau of Justice Statistics No. NCJ 222984). Bureau of Justice Statistics, Washington, DC, USA, pp. 1-25.

11. Greenfeld LA, Snell TL (1999) Women offenders. Washington, DC, USA: Bureau of Justice Statistics. Heritage Dictionaries.

12. Johnson T (2012) Mapping the critical service needs of adolescent children of prisoners. Soc Work Public Health 27(1-2): 45-68.

13. Johnston D (1995) Effects of parent incarceration. In: K. Gabel \& D. Johnston (Eds.), Children of incarcerated parents. Lexington Books, New York, USA, pp. 89-100.

14. Ministry of Home Affairs, Bureau of Police Reform (2012) Draft Policy in Police Training.

15. Ministry of Home Affairs, GOI (2003) Committee on Reforms of Criminal Justice System, para 1-3.

16. Pray KL (1943) Social work in the prison program. Fed. Probation 7(4): 3-7.

17. Pray KL, Towle C (1945) The place of social case work in the treatment of delinquency [with discussion]. Social Service Review 19(2): 235-248.

18. National Association of Social Workers (2012) Social work speaks: NASW policy statements. NASW Press, Washington, DC, USA. 
19. Travis J, Solomon AL, Waul M (2001) From prison to home: The dimensions and consequences of prisoner re-entry. Urban Institute, Washington, DC, USA

20. National Centre for Educational Statistics (2004) Literacy behind prison walls.

21. National Crime Records Bureau (2011) Crimes in New Delhi, India, Chapter-4.

22. National Institute of Corrections (2001) Provision of mental health care in prisons. Longmont, CO: National Institute of Corrections Information Centre.

23. Pettus-Davis C, Epperson MW (2014) From mass incarceration to smart decarceration. American Academy of Social Work and Social Welfare, Grand Challenges Initiative Concept Paper. St. Louis, MO Center for Social Development, George Warren Brown School of Social Work, Washington University in St. Louis, USA.

24.Vijay Raghvan (2013) Social work Intervention in Criminal Justice: Field-Theory Linkage. Social Work and Social Development, p. 265.

25. Reamer FG (2004) Social work and criminal justice: The uneasy alliance. Journal of Religion \& Spirituality in Social Work: Social Thought, 23(1-2): 213-231.

26. Rogers CR (1951) Client-centered therapy. Houghton Mifflin, Boston, MA, USA, pp. 560

27. Sabol WJ, West HC, Cooper M (2009) Prisoners in 2008. Department of Justice, Bureau of Justice Statistics, Washington, DC, USA.

28.SDTT (Sir Dorabji Tata Trust) (2011) Social Work in India's Criminal Justice Institutions: Need, Experiences and Challenges, Mumbai, India.

29. Severson MM (1994) Adapting social work values to the corrections environment. Social Work 39(4): 451-456.

This work is licensed under Creative

Commons Attribution 4.0 Licens

DOI: 10.19080/GJAA.2017.02.555580
30. Severson M, Postmus J, Berry M (2005) Incarcerated women: Consequences and contributions of victimization and intervention. International Journal of Prisoner Health 1(2-4): 223-240.

31. Solomon P, Draine J, Marcus SC (2002) Predicting incarceration of clients of a psychiatric probation and parole service. Psychiatr Serv 53(1): 50-56.

32. Toch H, Adams K (1986) Pathology and disruptiveness among prison inmates. Journal of Research in Crime and Delinquency 23(1): 7-21.

33. Veysey BM (1996) Effective strategies to provide mental health services to probationers with mental illnesses. In: A. J. Lurigio (Ed.), Responding to the mental and substance abuse health care needs for persons on probation. Seattle, WA: National Coalition for Mental and Substance Abuse Health Care in the Justice System.

34. Veysey BM (1998) Specific needs of women diagnosed with mental illnesses in U.S. jails. In: BL Levin, AK Blanch, A Jennings (Eds.), Women's mental health service: A public health perspective. Thousand Oaks, Sage, pp. 368-389.

35. Walmsley R (2009) World prison population list ( $8^{\text {th }}$ Ed.). London, England: International Centre for Prison Studies, King's College London, School of Law, UK.

36. West HC, Sabol WJ (2008) Prisoners in 2007. Washington, DC: Bureau of Justice Statistics, Department of Justice, USA.

37. White T, Schimmel D, Frickey R (2002) A comprehensive analysis of suicide in federal prisons: A fifteen-year review. Journal of Correctional Health Care 9(3): 321-343.

38. Wilson M (2010) Criminal justice social work in the United States: Adapting to new challenges. NASW Centre for Workforce Studies, Washington, DC, USA.

\section{Your next submission with Juniper Publishers will reach you the below assets}

- Quality Editorial service

- Swift Peer Review

- Reprints availability

- E-prints Service

- Manuscript Podcast for convenient understanding

- Global attainment for your research

- Manuscript accessibility in different formats

( Pdf, E-pub, Full Text, Audio)

- Unceasing customer service

Track the below URL for one-step submission https://juniperpublishers.com/online-submission.php 